\title{
A família Rubiaceae na Reserva Biológica Guaribas, Paraíba, Brasil. Subfamílias Antirheoideae, Cinchonoideae e Ixoroideae ${ }^{1}$
}

\author{
Maria do Socorro Pereira ${ }^{2,3,4}$ e Maria Regina de V. Barbosa ${ }^{2}$
}

Recebido em 07/09/2002. Aceito em 12/09/2003

\begin{abstract}
RESUMO - (A família Rubiaceae na Reserva Biológica Guaribas, Paraíba, Brasil. Subfamílias Antirheoideae, Cinchonoideae e Ixoroideae). Este trabalho consiste no levantamento dos representantes das subfamílias Antirheoideae, Cinchonoideae e Ixoroideae na Reserva Biológica Guaribas, Paraíba, Brasil. Foram realizadas coletas intensivas no período de outubro/2000 a outubro/2001, as quais resultaram no reconhecimento de 12 espécies, 10 gêneros e cinco tribos, distribuídos nas três subfamílias. A subfamília melhor representada foi Antirheoideae, com cinco espécies, quatro gêneros e duas tribos. Os gêneros com maior número de espécies foram Guettarda L. (2) e Tocoyena Aubl. (2). Alibertia A. Rich. ex DC., Alseis Schott, Chiococca P. Browne, Chomelia Jacq., Coutarea Aubl., Posoqueria Aubl., Sabicea Aubl. e Salzmannia DC. apresentaram uma única espécie cada. São apresentadas chaves para identificação, descrições, comentários sobre morfologia e distribuição das espécies, e ilustrações dos táxons verificados.
\end{abstract}

Palavras-chave: Rubiaceae, Nordeste do Brasil, Mata Atlântica, taxonomia

\begin{abstract}
The family Rubiaceae in the Guaribas Biological Reserve, Paraíba State, Brazil. Subfamilies Antirheoideae, Cinchonoideae and Ixoroideae). This paper is a survey of Rubiaceae subfamilies Antirheoideae, Cinchonoideae and Ixoroideae in the Guaribas Biological Reserve, Paraíba, Brazil. Intensive collections were made from October/2000 to October/2001. Twelve species, 10 genera and five tribes were recognized. The most diverse subfamily was Antirheoideae, with five species, four genera and two tribes. The genera with the most species were Guettarda L. (2) and Tocoyena Aubl. (2). Alibertia A. Rich. ex DC., Alseis Schott, Chiococca P. Browne, Chomelia Jacq., Coutarea Aubl., Posoqueria Aubl., Sabicea Aubl., and Salzmannia DC. were represented by only one species each. Keys, descriptions, comments on morphology and species distributions, as well as illustrations of the taxa are provided.
\end{abstract}

Key words: Rubiaceae, Northeastern Brazil, Atlantic Forest, taxonomy

\section{Introdução}

A família Rubiaceae engloba cerca de 637 gêneros e aproximadamente 10.700 espécies, classificadas em quatro subfamílias (Cinchonoideae, Ixoroideae, Antirheoideae e Rubioideae) e 44 tribos, essencialmente tropicais (Robbrecht 1988). Segundo Mabberley (1997), ela ocupa o quarto lugar em diversidade entre as Angiospermas, perdendo apenas para as Asteraceae, Orchidaceae e Fabaceae. Diversos gêneros são endêmicos da região neotropical, que apresenta cerca de 4.555 espécies (Andersson 1992). Psychotria L. é o maior gênero da família, representado mundialmente por cerca de 1.650 espécies (Hamilton 1989). Para o Brasil são estimados cerca de 96 gêneros (Barroso et al. 1986); para região Nordeste, Barbosa et al. (1996) compilaram 66 gêneros e 277 espécies.
Vários autores realizaram estudos taxonômicos na família, dentre estes destacam-se Hooker (1873), Schumann (1891), Standley (1930; 1931; 1936), Verdcourt (1958), Alain (1964), Bremekamp (1966), Steyermark (1972; 1974), Dwyer (1980), Rogers (1984), Burger \& Taylor (1993), Lorence (1994; 1999) e Delprete (1999).

No Brasil ainda são poucos os tratamentos taxonômicos para a família Rubiaceae, sendo os mais completos aqueles elaborados para a Flora Brasiliensis por Müller Argovensis (1881) e Schumann (1888; 1889). Os demais são estudos restritos a floras locais e publicações de novos táxons (Smith \& Downs, 1956; Sucre 1959; 1960/1961; 1971; Porto et al. 1977; Dillenburg \& Porto 1985; Barbosa \& Peixoto 1989; Jung-Mendaçolli 1994; 1999; Cabral 1996; Cabral \& Bacigalupo 2000). Para a região Nordeste há apenas algumas referências: Figueiredo et al. (1990), Zappi

\footnotetext{
1 Parte da Dissertação de Mestrado da primeira Autora

2 Departamento de Sistemática e Ecologia, CCEN, Universidade Federal da Paraíba, C. Postal 5065, Cidade Universitária, CEP 58051-970, João Pessoa, PB, Brasil. Bolsa CNPq (mregina@dse.ufpb.br)

3 Programa de Pós-Graduação em Biologia Vegetal, PPGBV, Universidade Federal de Pernambuco, UFPE. Bolsa CNPq

4 Autor para correspondência: m.s_pereira@bol.com.br
} 
\& Stannard (1995), Barbosa et al. (1996), Souza (1997), Barbosa \& Peixoto (2000) e Zappi \& Nunes (2000). Para o Estado da Paraíba existem somente dois trabalhos sobre a família Rubiaceae: a publicação de uma nova espécie, Guettarda grazielae M.R. Barbosa, elaborada por Barbosa (1997), e o levantamento do gênero Psychotria, realizado por Pereira (1996).

O objetivo deste trabalho foi o de realizar o levantamento da família Rubiaceae, subfamílias Antirheoideae, Cinchonoideae e Ixoroideae na Reserva Biológica Guaribas, importante remanescente de Mata Atlântica ao norte do Estado e dessa forma, contribuir para o conhecimento da flora da Mata Atlântica nordestina e da flora local, bem como, fornecer subsídios para futuros estudos taxonômicos na família.

\section{Material e métodos}

A Reserva Biológica Guaribas está localizada nos municípios de Mamanguape e Rio Tinto, a $6^{\circ} 44^{\prime} 02^{\prime}$ "

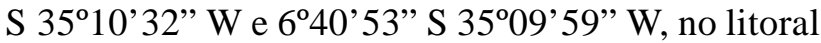
norte do Estado da Paraíba, a 70km da capital João Pessoa (Fig. 1). Possui extensão territorial significativa com 4.321 ha, divididos em três áreas distintas: Área I, localizada em Mamanguape, com superfície de 616ha, constituída por manchas de cerrado (áreas abertas, com solo arenoso, conhecidas na região como tabuleiros) e remanescentes de mata atlântica; Área II, também situada em Mamanguape, com 3.378ha, onde a cobertura vegetal predominante é a mata atlântica, e Área III, localizada em Rio Tinto, com superfície de 327 ha que, embora seja a menor área, apresenta trechos bem conservados da floresta nativa e áreas de tabuleiros.

Foram realizadas coletas mensais aleatórias, buscando abranger toda a reserva, no período de outubro/2000 a outubro/2001, nas quais foram observadas e anotadas características referentes ao hábito, morfologia, coloração das inflorescências, brácteas, flores e frutos. O material coletado encontra-se depositado no herbário Lauro Pires Xavier (JPB) e duplicatas no herbário Geraldo Mariz (UFP). As siglas estão de acordo com Holmgren et al. (1990).

Adotou-se o sistema de classificação de Robbrecht (1988) para delimitação dos táxons supragenéricos. A terminologia para caracterização das folhas e das inflorescências foi baseada em Rizzini (1977) e Vidal \& Vidal (1990), respectivamente; a de frutos e sementes segue Barroso et al. (1999). As

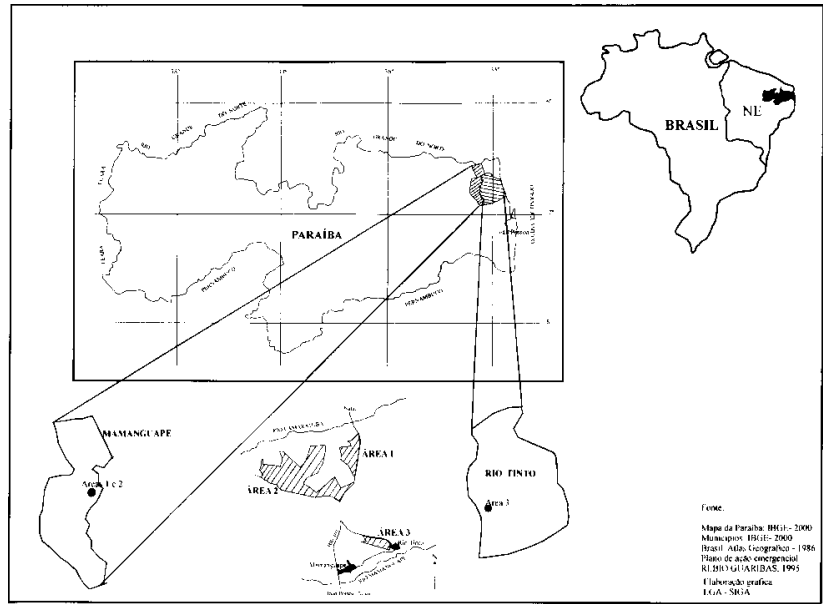

Figura 1. Cartograma de localização da Reserva Biológica Guaribas.

abreviaturas dos nomes de autores seguem Brummitt \& Powell (1992).

A identificação do material foi realizada a partir de análises morfológicas detalhadas, com o auxílio de chaves analíticas, descrições e diagnoses encontradas na literatura especializada e, quando possível, através da análise de tipos ou fotografias dos tipos.

As chaves para separação dos gêneros e das espécies, bem como as descrições e as ilustrações, foram elaboradas com base apenas no material proveniente da Reserva Biológica Guaribas.

\section{Resultados e discussão}

Rubiaceae Juss.

Árvores, arbustos, subarbustos, ervas ou plantas volúveis. Ramos lisos ou estriados, cilíndricos ou comprimidos lateralmente, glabros ou pilosos. Estípulas interpeciolares inteiras, bipartidas, bífidas ou fimbriadas, persistentes ou caducas, glabras ou pilosas. Folhas sésseis ou pecioladas, simples, opostas, opostas-cruzadas ou verticiladas, lanceoladas, oblongo-lanceoladas, oblongas, ovadas ou obovadas, glabras ou pilosas. Inflorescências sésseis ou pedunculadas, racemosas ou cimosas, terminais ou axilares, brácteas presentes ou ausentes. Flores andróginas ou unissexuais, sésseis ou pediceladas. Cálice subulado, campanulado, truncado ou subtruncado, 2-6 laciniado, persistente ou decíduo, glabro ou piloso. Corola tubulosa, infundibuliforme, hipocrateriforme ou campanulada, tetra-hexâmera, branca, amarela, roxa, azul, rosada ou esverdeada, 
glabra ou pilosa. Estames 4-6, exsertos ou inclusos, alternos aos lobos da corola; filetes glabros ou pilosos; anteras oblongas ou lineares, dorsifixas ou basifixas, glabras ou pilosas. Ovário ínfero, bi-multilocular, um a muitos óvulos por lóculo. Estilete em geral exserto, inteiro, capitado, bífido ou bilobado. Frutos deiscentes ou indeiscentes, capsulares, esquizocárpicos, drupáceos ou bacáceos, brancos, vermelhos, amarelos, alaranjados, roxos, azuis, negros, castanhos, esverdeados ou castanhos, glabros ou pilosos.

Chave para as subfamílias, tribos e espécies de Rubiaceae na

Reserva Biológica de Guaribas, PB, Brasil

1. Prefloração da corola valvar ou raramente imbricada

2. Um só óvulo por lóculo .

I. Subfamília Antirheoideae

3. Estames inseridos na base do tubo da corola, concrescidos na base Tribo Chiococceae

4. Inflorescências em racemos, corola pentâmera, ovário comprimido lateralmente, estilete inteiro, frutos brancos

1. Chiococca alba

4. Inflorescências em glomérulos, corola tetrâmera, ovário não comprimido, estilete bipartido a bífido, frutos vermelhos

2. Salzmannia nitida

3. Estames inseridos na fauce ou na porção mediana do tubo da corola, livres entre

si

Tribo Guettardeae

5. Corola tetrâmera, fruto cilíndrico

3. Chomelia obtusa

5. Corola pentâmera ou hexâmera, fruto globoso

6. Árvores com mais de $3 \mathrm{~m}$ alt., folhas oblongo-ovadas, lâmina 12-19,5×7-12,5cm, corola hexâmera

4. Guettarda grazielae

6. Arbustos com menos de $3 \mathrm{~m}$ alt., folhas lanceoladas, lâmina 4-9×2,5-5cm, corola pentâmera

5. Guettarda platypoda

2. Muitos óvulos por lóculo

II. Subfamília Cinchonoideae

7. Árvores, com frutos capsulares Tribo Cinchoneae

8. Inflorescências em racemos espiciformes, corola campanulada, branco-amarelada ou amarelo-esverdeada, tubo ereto, anteras oblongas, dorsifixas 6. Alseis pickelii

8. Inflorescências em panículas corimbiformes, corola infundibuliforme, rosada, tubo curvo, anteras lineares, basifixas

7. Coutarea hexandra

7. Trepadeiras volúveis, com frutos bacáceos Tribo Isertieae - 8. Sabicea cinerea

1. Prefloração da corola contorta

9. Flores unissexuais III. Subfamília Ixoroideae - Tribo Gardenieae

9. Flores andróginas

9. Alibertia myrciifolia

10. Botões florais curvos no ápice, geniculados, anteras pilosas

10. Botões florais não curvos no ápice, eretos, anteras glabras

11. Folhas tomentosas em ambas as faces, estípulas caducas

10. Posoqueria longiflora

11. Folhas glabras em ambas as faces, estípulas persistentes

11. Tocoyena formosa

12. Tocoyena sellowiana

\section{Subfamília Antirheoideae Raf.}

Plantas geralmente lenhosas, raramente herbáceas; estípulas inteiras; corola com lobos valvares, raramente imbricados ou contortos; um óvulo por lóculo, óvulos em geral pêndulos; frutos geralmente carnosos.

\section{Tribo Chiococceae Hook. f.}

Árvores ou arbustos; inflorescências axilares, raramente terminais; corola com lobos valvares, raramente imbricados; estames inseridos na base do tubo da corola, filetes concrescidos na base; ovário bilocular.

1. Chiococca alba (L.) Hitchc., Annual Rep. Missouri Bot. Gard. 4: 94. 1893.

Lonicera alba L. Sp. Pl. 175. 1753.

Fig. 2-7.

Arbusto, 1-2m alt., ramificado. Ramos lisos a parcialmente estriados, espessos nos nós, cilíndricos, castanhos, glabros a pubérulos; entrenós $2-4 \mathrm{~cm}$ compr. Estípulas 2-3×2-2,5mm, inteiras, triangulares, agudas, 


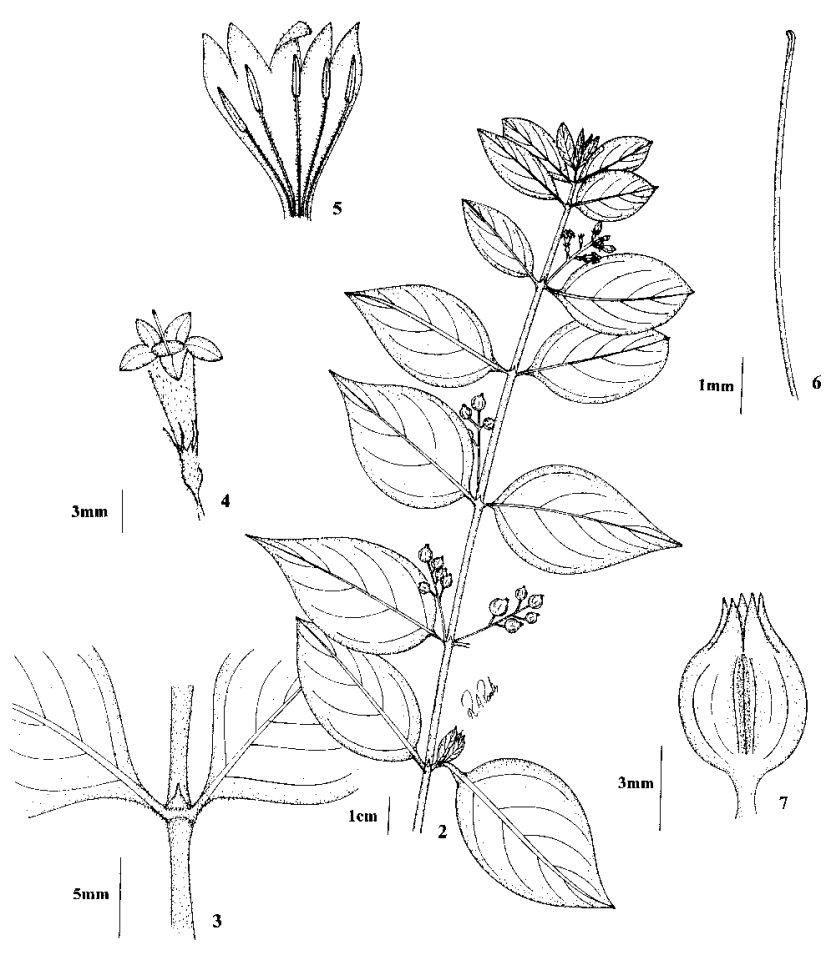

Figuras 2-7. Chiococca alba (Pereira 522): 2. Ramo florido e frutificado. 3. Estípula. 4. Flor. 5. Corola aberta. 6. Estilete e estigma. 7. Fruto.

esverdeadas, pubérulas, tricomas curtos, eretos, macios. Folhas pecioladas, lâmina 3,5-6×2-4cm, lanceolado-ovada, base arredondada, ápice agudo, margem inteira, membranácea, castanha quando seca, face superior glabra, face inferior hirsuta, 3-5 pares de nervuras secundárias; pecíolo 2-3×1-1,5mm, esverdeado, com tricomas curtos, eretos, macios. Racemos axilares, $1,5-2 \times 1-1,5 \mathrm{~cm}$, pedunculados, com (4)-7-9-(11) flores dispostas lateralmente; 1 bractéola na base de cada flor com $1-2 \times 1-1,5 \mathrm{~mm}$, linear, castanha, pilosa, hirsuta; pedúnculo $0,5-1,5 \times 0,1-0,2 \mathrm{~cm}$, esverdeado, tricomas curtos, eretos, macios. Flores andróginas, pediceladas, pedicelo com 3-4×1-2mm, esverdeado, hirsuto; botões florais oblongos a alongados, com ápice agudo. Cálice subulado, esverdeado, 5-laciniado, persistente, 1-1,5×1-1,2mm, hirsuto. Corola infundibuliforme, hirsuta externamente e glabra internamente, branco-amarelada, pentâmera, tubo 4-5×1-2,5mm, lobos 1-2×1-1,5mm, oblongos. Estames 5, inclusos, presos na base da corola; filetes 2-3mm compr., concrescidos na base, hialinos, hirsutos; anteras 3-3,5 $\times 0,5-1 \mathrm{~mm}$, oblongas, agudas, dorsifixas, branco-amareladas, glabras. Hipanto $2-3 \times 1-1,5 \mathrm{~mm}$, hirsuto. Ovário comprimido lateralmente, bilocular, uniovular, óvulos pêndulos, presos no ápice do septo, disco nectarífero inteiro. Estilete terminal, exserto, inteiro, 0,8-1 cm compr., glabro; estigma inteiro, 0,2-0,5mm compr., glabro. Drupa 4,8-5×4-6mm, comprimida lateralmente, orbicular, branca, glabra a hirsuta. Pirênios 4,8-5×3,8-4,5mm, livres entre si, comprimidos, lisos.

Material selecionado: BRASIL. Paraíba: Mamanguape, Área I, 23/III/2001, fr., Pereira 325 (JPB); 29/VII/2001, fr., Pereira 522 (JPB); 5/X/2001, fr., Pereira 607 (JPB); Área II, 6/III/1990, fl., fr., Félix \& Santana 2753 (JPB); 16/VI/2000, fl., Pereira 164 (JPB); 16/VI/2000, fr., Pereira 169 (JPB); 12/I/2001, fl., Pereira 255 (JPB); 12/I/2001, fr., Pereira 261 (JPB); 23/II/2001, fr., Pereira 276 (JPB); 22/III/2001, fr., Pereira 294 (JPB); 29/VI/2001, fr., Pereira 482 (JPB); 28/IX/2001, fr., Pereira 594 (JPB). Rio Tinto, Área III, 19/VIII/1988, fr., Félix \& Miranda 27 (JPB); 30/V/2001, fr., Pereira 387 (JPB); 30/V/2001, fl. fr., Pereira 390 (JPB).

Material adicional: BRASIL. Paraíba: Areia, 6/VIII/1942, fr., Xavier s.n. (JPB), 11/II/2000, fl., Grisi 80 (JPB); Cabedelo, 18/XII/1981, fl., fr., Xavier-Filho s.n. (JPB), 30/VII/1999, fr., Pontes 86 (JPB), 10/XI/1999, fl., Pontes \& Gadelha-Neto 266 (JPB), 31/01/2000, fl., Pontes \& Lima 407 (JPB); João Pessoa, 6/VIII/1995, fr., Moura 119 (JPB). Pernambuco: Caruaru, 20/III/1998, fr., Pereira 88 (JPB).

Chiococca alba tem distribuição neotropical (Steyermark 1974; Lorence 1999). Para o Brasil foi citada por Jung-Mendaçolli (1999) como espécie umbrófila, habitando florestas de encosta e restingas arbóreas no Estado de São Paulo. Zappi \& Stannard (1995) e Barbosa et al. (1996) citam esta espécie para a região Nordeste, e na Paraíba é citada por Pontes (2000) para área de restinga arbórea. Na REBIO Guaribas, foi encontrada tanto nas áreas de mata, especialmente em lugares sombreados, como também em tabuleiros. Floresce e frutifica nos mais variados meses do ano, principalmente de janeiro a novembro.

\section{Salzmannia nitida DC., Prodr., 4: 617. 1830.}

Fig. 8-9.

Arbusto, 0,5-2m alt., ramificado. Ramos estriados, resinosos, espessos nos nós, cilíndricos, lúcidos, castanhos, glabros; entrenós 3-6,5cm compr. Estípulas 1-2×3-4mm, inteiras, truncadas, esverdeadas, glabras. Folhas pecioladas, lâmina 3,5-8,5×2,5-5,5cm, oblongoovada a oblongo-lanceolada, base obtusa a aguda, ápice obtuso a agudo, margem inteira, revoluta, cartácea, lúcida, verde a castanha quando seca, glabra em ambas as faces, 6-8 pares de nervuras secundárias; pecíolo 
0,6-1×0,1-0,2cm, esverdeado, glabro. Glomérulos axilares, $0,7-1 \times 0,6-1 \mathrm{~cm}$, sésseis a subsésseis, com (4)-7-10-(14) flores por glomérulo, 2 brácteas involucrais com $7-9 \times 4-5 \mathrm{~mm}$, foliáceas, oblongas, lúcidas, esverdeadas, glabras em ambas as faces; pedúnculo 1-3×1-1,5mm, esverdeado, glabro. Flores andróginas, sésseis, botões florais oblongos, com ápice agudo. Cálice esverdeado, 4-laciniado, persistente, 1-1,2×1-1,5mm, glabro. Corola tubulosa a hipocrateriforme, glabra, amarela, tetrâmera, tubo 3-3,5×1-1,5mm, lobos 0,5-0,7×0,3-0,5mm, triangulares. Estames 4, inclusos, presos na base da corola; filetes 1,2-1,4mm compr., concrescidos na base, glabros; anteras 2-3×0,2-0,5mm, oblongas, agudas, dorsifixas, amareladas, glabras. Hipanto 2-3×1-2mm, glabro. Ovário bilocular, uniovular, óvulos pêndulos, fixos no ápice do septo, disco nectarífero inteiro. Estilete terminal, exserto, bipartido a bífido, 3-4mm compr., glabro; ramos dos estilete $0,3-0,5 \mathrm{~mm}$ compr., glabros. Drupa 4-7×3-6mm, globosa, vermelha, glabra. Pirênios 3,5-6×2,5-6,5mm, livres entre si, globosos, lisos.

Material selecionado: BRASIL. Paraíba: Mamanguape, Área I, 18/VIII/1988, fl., Félix \& Miranda 34 (JPB); 13/XII/2000, fl., Pereira 231 (JPB); 23/III/2001, fl., Pereira 332 (JPB); 27/IV/2001, fl. fr., Pereira 363 (JPB); 29/VII/2001, fr., Pereira 527 (JPB); 5/X/2001, fl., Pereira 622 (JPB); Área II, 13/VI/1991, fl., Félix \& Souza 3980 (JPB); 6/VII/1998, fl., Félix \& Miranda s.n. (JPB); 16/VI/2000, fr., Pereira 171 (JPB); 12/I/2001, fr., Pereira 254 (JPB); 23/II/2001, fr., Pereira 267 (JPB); 22/III/2001, fl., Pereira 291 (JPB); 29/VI/2001, fr., Pereira 484 (JPB); 29/VI/2001, fl., Pereira 490 (JPB); 28/IX/2001, fr., Pereira 593 (JPB). Rio Tinto, Área III, 30/VIII/2001, fl., Pereira 573 (JPB); 30/VIII/2001, fl. fr., Pereira 574 (JPB).

Material adicional: BRASIL. Bahia: Ilhéus, 29/IX/1980, fl., Mattos-Silva et al. 1109 (JPB). Paraíba: João Pessoa, 11/XII/1986, fl., Miranda 305 (JPB); Santa Rita, 6/IV/1983, fr., Agra 432 (JPB), 22/IX/1987, fr., Agra 640 (JPB). Pernambuco: Cabo de Santo Agostinho, 29/IX/1989, fl. fr., Agra 764 (JPB).

Salzmannia nitida tem distribuição neotropical, principalmente em áreas litorâneas, sendo referida por Müller Argovensis (1881), Andersson (1992), Barbosa (1996) e Barbosa et al. (1996) para várias regiões do Brasil e outros países do continente americano. Caracteriza-se por apresentar inflorescências em glomérulos axilares, corola tetrâmera, amarela, ovário não comprimido lateralmente, estilete partido e frutos vermelhos, apresentando ainda substâncias resinosas nos ramos. Ocorre nas três áreas da Reserva Biológica Guaribas, especialmente nos tabuleiros ou nas áreas de transição mata-tabuleiro. Floresce e frutifica praticamente em todos os meses do ano.

Tribo Guettardeae DC.

Árvores, arvoretas ou arbustos; inflorescências terminais ou axilares; corola com lobos valvares, raramente imbricados; estames inseridos na fauce ou na porção mediana do tubo da corola, livres entre si; ovário bi-multilocular.

3. Chomelia obtusa Cham. \& Schltdl., Linnaea 4: 185. 1829.

Árvore, 4-5m alt. Ramos estriados, flexuosos, cilíndricos, branco-acinzentados, castanhos a ferrugíneos, glabros a hirsutos quando jovens; entrenós 4-6,5cm compr., presença de escamas nos ramos jovens. Estípulas 1-2,5×2-3mm, inteiras, lineares, esverdeadas, castanhas a ferrugíneas, escabras a hirsutas. Folhas pecioladas, lâmina 3,5-6,5×2-4cm, oblongo-lanceolada, base obtusa, ápice obtuso, margem inteira, membranácea, castanha a ferrugínea quando seca, face superior glabra, face inferior hirsuta; 3-5 pares de nervuras secundárias; pecíolo 3-4×0,5-1mm, esverdeado, hirsuto. Cimas umbeliformes axilares, laxas, 1,5-3,5×1-2cm, pedunculadas, com (2)-3-4-(6) flores por cima; 1 bractéola na base de cada flor com 0,5-1×0,3-0,5mm, linear, esverdeada, pilosa; pedúnculo $1,0-2,5 \times 0,5-0,1 \mathrm{~cm}$, esverdeado, glabro. Flores andróginas, sésseis, botões florais alongados, com ápice agudo. Cálice subulado, verde, 4-laciniado, persistente, 1,5-2,5×0,5-0,2cm, hirsuto. Corola tubulosa a hipocrateriforme, hirsuta externamente e glabra internamente, branca, tetrâmera, tubo 1,2-1,5x 0,1-0,2cm, lobos 1-2×0,5-1mm, oblongos. Estames 4, inclusos, presos na porção mediana do tubo, sésseis; anteras $0,5-1 \times 0,2-0,3 \mathrm{~mm}$, oblongas, apiculadas, dorsifixas, esbranquiçadas, glabras. Hipanto 2-2,5x 1,5-2mm, glabro. Ovário bilocular, uniovular, óvulos pêndulos, afixados no ápice do septo, disco nectarífero inteiro. Estilete terminal, exserto, bipartido, bífido, 1,6-1,8cm compr., glabro; ramos do estilete $0,2-0,3 \mathrm{~mm}$ compr., glabros, superfície estigmática papilosa. Drupa 6-8 $\times 2-3 \mathrm{~mm}$, oblonga, cilíndrica a subcilíndrica, castanha, glabra. Pirênios 5-7×1-1,5mm, concrescidos em um só, linear-oblongos, lisos.

Material selecionado: BRASIL. Paraíba: Mamanguape, Área II, 21/XII/1989, fl. fr., Félix \& Santana 2620 (JPB); 29/VII/2001, fr., Pereira 543 
(JPB); 29/VII/2001, fl., Pereira 549 (JPB); 28/IX/2001, fr., Pereira 583 (JPB).

Material adicional: BRASIL. Paraíba: João Pessoa, 10/VII/1993, fl., Moura 976(JPB); Mataraca, 1/IX/1993, fl., Moura 1083 (JPB); Santa Rita, 28/II/1994, fl., Moura 1221 (JPB).

Chomelia obtusa tem distribuição neotropical (Andersson 1992). No Brasil é encontrada em São Paulo, Minas Gerais, Goiás, Mato Grosso (Müller Argovensis 1881) e na região Nordeste (Barbosa et al. 1996). Diferencia-se das demais espécies estudadas por apresentar corola tetrâmera e frutos cilíndricos ou subcilíndricos. Em Guaribas é encontrada apenas nas áreas de mata, geralmente em lugares bastante sombreados. Floresce em fevereiro, julho, setembro, dezembro e frutifica em julho, setembro, dezembro.

4. Guettarda grazielae M.R. Barbosa, Bradea 8(11): 61-63. 1997.

Fig. 10-12.

Árvore ou arvoreta, 3,5-5m alt. Ramos estriados, comprimidos lateralmente, cinéreos, castanhos, glabros a pubérulos quando jovens; entrenós 4,5-7,5cm compr. Estípulas $0,7-1 \mathrm{~m} \times 0,4-0,5 \mathrm{~cm}$, inteiras, triangulares, agudas, amarelo-esverdeadas, pubescentes, tricomas longos, macios. Folhas pecioladas, lâmina 12-19,5×7$12,5 \mathrm{~cm}$, oblongo-ovada, base obtusa, ápice obtuso, margem inteira, cartácea a subcoriácea, castanha a esbranquiçada quando seca, face superior glabra, face inferior pubescente, 9-11 pares de nervuras secundárias; pecíolo 1,5-3,5×0,2-0,3cm, esverdeado, tomentoso. Cimas escorpióides axilares, 11-14× 1,5-3cm, pedunculadas, dicotômicas, com (10)-14-18(22) flores por cima; 1 bractéola na base de cada flor com 4-5 $\times 2-3 \mathrm{~mm}$, linear, castanha, pubescente; pedúnculo 10-13×0,1-0,2cm, esverdeado, pubescente, tricomas macios, hialinos. Flores andróginas, sésseis, botões florais oblongos, com ápice agudo a obtuso. Cálice truncado, branco-esverdeado, persistente, 2-3×2-2,5mm, pubescente, hirsuto. Corola tubulosa a hipocrateriforme, tomentosa externamente e glabra internamente, branca, hexâmera, tubo 1,3-1,5× 0,1-0,3cm, lobos 3-4×1-2mm, oblongos. Estames 6, inclusos, presos na porção mediana do tubo, sésseis; anteras 3-3,5×0,1-0,2mm, oblongas, apiculadas, dorsifixas, branco-amareladas, glabras. Hipanto 3-4×2-2,5mm, piloso. Ovário tri-tetralocular, uniovular, óvulos pêndulos, afixados no ápice do septo, disco nectarífero inteiro. Estilete terminal, incluso, inteiro, 1,4-1,6cm compr., piloso; estigma capitado, 1-1,2mm compr., glabro. Drupa 2,5-3,5×2,5-4mm, globosa, branca, pubérula, escabra. Pirênios 2-3×2-3,5mm, concrescidos em um só, globosos, lisos.

Material selecionado: BRASIL. Paraíba: Mamanguape, Área II, 29/VII/2001, fr., Pereira 533 (JPB). Rio Tinto, Área III, 30/V/2001, fl., Pereira 400 (JPB); 30/V/2001, fr., Pereira 408 (JPB); 30/V/2001, fl., Pereira 410 (JPB); 30/V/2001, fl., Pereira 416 (JPB).

Material adicional: BRASIL. Paraíba: João Pessoa, 5/II/1988, fl., Agra 642 (JPB); 3/V/1991, fl. fr., Agra 1312 (JPB); 13/III/1992, fl., Barbosa 1267 (JPB).

Guettarda grazielae ocorre em pequena concentração no subosque de remanescentes de mata atlântica no litoral paraibano, onde a família Rubiaceae apresenta grande riqueza de espécies (Barbosa 1996). G. grazielae é proxima de G. platypoda DC., porém, difere pelo hábito arbóreo e pelas dimensões bem maiores das folhas, flores e frutos (Barbosa 1997).

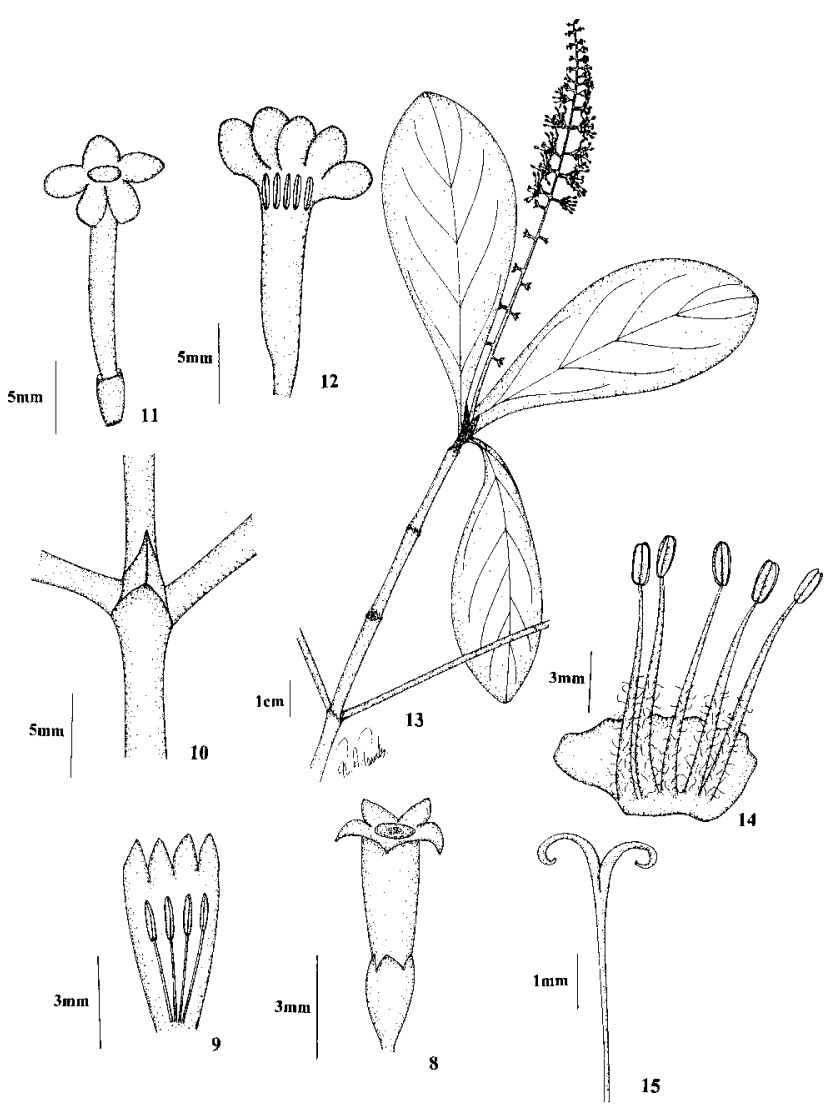

Figuras 8-15. Salzmannia nitida (Pereira 490): 8. Flor. 9. Corola aberta. Guettarda grazielae (Pereira 410): 10. Estípula. 11. Flor. 12. Corola aberta. Alseis pickelii (Pereira 631): 13. Ramo florido. 14. Corola aberta. 15. Estilete e estigma. 
Em Guaribas é encontrada apenas no interior da mata. Floresce em fevereiro, maio e frutifica em maio, julho.

\section{Guettarda platypoda DC., Prodr. 4: 456. 1830.}

Arbusto, 1-2,5m alt., ramificado. Ramos estriados, espessos, cilíndricos, castanhos a ferrugíneos, glabros a pubérulos quando jovens; entrenós 2-6cm compr. Estípulas 3-4×2-3mm, inteiras, triangulares, agudas, amarelo-esverdeadas, pubescentes, tricomas longos, macios. Folhas pecioladas, lâmina $4-9 \times 2,5-5 \mathrm{~cm}$, lanceolada, base aguda, ápice agudo, margem inteira, cartácea a subcoriácea, castanha a esbranquiçada quando seca, face superior glabra, face inferior pubescente, tricomas macios, hialinos, 7-10 pares de nervuras secundárias; pecíolo 3-5×1-2mm, verde, pubérulo. Cimas escorpióides axilares, 2,5-7×1-2cm, pedunculadas, dicotômicas, com (5)-9-12-(18) flores por cima, 1 bractéola na base de cada flor com 2-3×1-2mm, linear, castanha, pubescente; pedúnculo 1,5-4×0,1-0,2cm, verde, piloso, escabro. Flores andróginas, sésseis, botões florais oblongos, com ápice agudo a obtuso. Cálice truncado, branco-esverdeado, persistente, 1-1,5×1,5-2mm, pubescente. Corola tubulosa a hipocrateriforme, tomentosa externamente e glabra internamente, branca, pentâmera, tubo 6-8×1,5-3mm, lobos 2-3×1-1,5mm, oblongos. Estames 5 , inclusos abaixo da fauce; filetes $0,5-1 \mathrm{~mm}$ compr., glabros; anteras 1-1,5×0,3-0,5mm, oblongas, apiculadas, dorsifixas, branco-amareladas, glabras. Hipanto 2-3×1,5-2mm, piloso. Ovário tetralocular, uniovular, óvulos pêndulos, afixados no ápice do septo, disco nectarífero inteiro. Estilete terminal, incluso, inteiro, 5-7mm compr., piloso; estigma capitado, 0,5-1mm compr., glabro. Drupa 2-3×2-3mm, globosa, branca, pubérula, escabra. Pirênios 2-2,5×2-2,5mm, concrescidos em um só, globosos, lisos.

Material selecionado: BRASIL. Paraíba: Mamanguape, Área I, 27/VI/2001, fl., Pereira 365 (JPB); 29/VII/2001, fl., Pereira 529 (JPB); 29/VII/2001, fr., Pereira 531 (JPB); 5/X/2001, fl., Pereira 608 (JPB); 5/X/2001, fr., Pereira 621 (JPB); Área II, 15/VI/2000, fl., Pereira 146 (JPB); 15/VI/2000, fr., Pereira 147 (JPB); 15/VI/2000, fl. fr., Pereira 151 (JPB); 22/X/2000, fl. fr., Pereira 200 (JPB); 12/I/2001, fl., Pereira 260 (JPB); 22/III/2001, fr., Pereira 301 (JPB); 27/IV/2001, fl., Pereira 339 (JPB); 28/IX/2001, fl., Pereira 589(JPB); 28/IX/2001, fr., Pereira 592 (JPB). Rio Tinto, Área III, 15/XI/2000, fl., Pereira 223 (JPB); 30/V/2001, fr., Pereira 371 (JPB); 30/V/2001, fl. fr., Pereira 372 (JPB).
Material adicional: BRASIL. Paraíba: Cabedelo, 2/VII/1999, fl., Pontes 57 (JPB); 19/I/2000, fl., Pontes \& Lima 383 (JPB). Jacaraú, 16/IX/1982, fl., Agra 210 (JPB). João Pessoa, 10/III/1992, fl., Barbosa 1263 (JPB). Santa Rita, 21/IX/1978, fl., Agra 68 (JPB).

Guettarda platypoda tem distribuição neotropical (Andersson 1992). No Brasil ocorre em regiões litorâneas, principalmente no Nordeste (Müller Argovensis 1881; Barbosa et al. 1996; Pontes 2000). Apresenta hábito arbustivo, folhas, flores e frutos com dimensões menores que $G$. grazielae de quem é próxima. Em Guaribas é comumente encontrada nos tabuleiros, no subosque da mata ou ainda em áreas de transição mata-tabuleiro. Floresce e frutifica praticamente todos os meses do ano.

II. Subfamília Cinchonoideae Raf.

Plantas lenhosas, freqüentemente arbóreas ou arbustivas, lianas em Isertieae; estípulas inteiras; corola com lobos valvares ou imbricados, raramente contortos; muitos óvulos por lóculo; frutos em geral deiscentes, capsulares, raramente carnosos.

Tribo Cinchoneae DC.

Árvores; inflorescências terminais; ovário bilocular; frutos capsulares.

6. Alseis pickelii Pilg. \& Schmale, Repert. Sp. Nov. 41: 222. 1937.

Fig. 13-15.

Árvore ou arvoreta, 2,5-8m alt. Ramos estriados, espessos, cilíndricos, castanho-acinzentados, glabros; entrenós 3-5cm compr. Estípulas 1-6×1,5-2mm, inteiras, triangulares a ligeiramente oblongas, agudas a curtoacuminadas, castanhas, glabras a pubérulas nas margens. Folhas pecioladas, lâmina $4-11 \times 2,5-4 \mathrm{~cm}$, obovada, base aguda a atenuada, ápice obtuso, margem inteira, membranácea, castanho-esverdeada quando seca, face superior glabra, face inferior pilosa apenas na axila das nervuras secundárias (domáceas); 5-11 pares de nervuras secundárias; pecíolo 4-7×1-2mm, castanho, glabro. Racemos espiciformes terminais, $11-17 \times 1,5-2,5 \mathrm{~cm}$, pedunculados, com (32)-60-68-(102) flores por racemo, 1 bractéola na base de cada flor com 1-2×0,2-0,5mm, linear a lanceolada, castanha, hirsuta; pedúnculo 2,5-4cm $\times 2-3 \mathrm{~mm}$, castanhoacinzentado, glabro. Flores andróginas, sésseis, botões florais oblongos, arredondados, com ápice obtuso a arredondado. Cálice subulado, castanho-esverdeado, 
5-laciniado, persistente, 1-2×1-1,5mm, glabro. Corola campanulada, branco-amarelada a amareloesverdeada, pentâmera, tubo 1,5-2×2-3mm, ereto, glabro externamente e hirsuto internamente, da base até a fauce, lobos $0,1-0,3 \times 0,2-0,5 \mathrm{~mm}$, triangulares, agudos, glabros. Estames 5, exsertos, afixados na base da corola; filetes 7-9mm compr., pilosos da base até a porção mediana; anteras 1-1,5×0,5-1 mm, oblongas, obtusas, curto-apiculadas, dorsifixas, amareladas, glabras. Hipanto 2-3×1-2mm, glabro. Ovário bilocular, pluriovular, óvulos pêndulos afixados na axila do septo, disco nectarífero inteiro. Estilete terminal, exserto, bífido, revoluto, 4-5mm compr., glabro; ramos do estilete 1-2mm compr., lineares a lanceolados. Cápsula 1,5-2,2×0,2-0,4cm, subcilíndrica, lenhosa, separando-se longitudinalmente em duas valvas, do ápice para a base, castanha a ferrugínea, glabra. Sementes 1,2-1,8× 0,1-0,2cm, fusiformes, com estrias longitudinais.

Material selecionado: BRASIL. Paraíba: Mamanguape, Área I, 23/III/2001, fr., Pereira 336 (JPB); Área II, 11/VI/1991, fr., Félix \& Miranda 3434 (JPB); 23/II/2001, fr., Pereira 286 (JPB); 22/III/2001, fr., Pereira 319 (JPB); 27/IV/2001, fr., Pereira 338 (JPB); 28/IX/2001, fl., Pereira 601 (JPB); 5/X/2001, fl., Pereira 631 (JPB); 5/X/2001, fr., Pereira 635 (JPB). Rio Tinto, Área III, 30/VIII/2001, fl., Pereira 561 (JPB).

Material adicional: BRASIL. Paraíba: Cuité, 1/VI/1992, fr., Agra \& Pereira 1920 (JPB). João Pessoa, 1/X/1986, fr., Moura 231 (JPB); 4/IX/1993, fl., Moura 1089 (JPB); 18/I/1995, fl., Barbosa 1421 (JPB).

Alseis pickelii é uma espécie que tem ocorrência neotropical. No Brasil é comum na região Nordeste, em áreas de mata atlântica, matas de altitude ou ainda em restingas arbóreas (Andersson 1992; Barbosa 1996). Caracteriza-se por apresentar inflorescências dispostas em racemos espiciformes e corola campanulada com tubo ereto. Em Guaribas é encontrada nas três áreas da unidade, na mata úmida e nos tabuleiros. Floresce em janeiro, agosto, setembro, outubro e frutifica em fevereiro, março, abril, junho, outubro.

7. Coutarea hexandra (Jacq.) K. Schum., Fl. Bras. 6(6): 196. 1889.

Portlandia hexandra Jacq., Enum. Pl. Carib. 16. 1760.

Fig. 16-20.

Árvore ou arvoreta, 3-5m alt. Ramos lisos a parcialmente estriados, espessos nos nós, cilíndricos, castanhos, glabros, com lenticelas amareladas a esbranquiçadas; entrenós 3-6,5cm compr. Estípulas $3-4 \times 4-5 \mathrm{~mm}$, inteiras, triangulares, agudas, castanhas, glabras a pubérulas nas margens. Folhas pecioladas, lâmina 8,5-15×5,5-7,5cm, lanceolado-ovada a largamente lanceolada, base aguda a obtusa, ápice agudo, margem inteira a revoluta, membranácea, castanha a castanho-acinzentada quando seca, glabra em ambas as faces, 6-8 pares de nervuras secundárias, com a principal proeminente na face inferior; pecíolo 5-9×1-1,5mm, castanho, glabro. Panículas corimbiformes terminais, $6,5-8,5 \times 3-6,5 \mathrm{~cm}$, pedunculadas, com (6)-9-14-(16) flores por panícula, 2 bractéolas na base de cada flor com 4-5×1-2mm, lineares, castanhas, glabras; pedúnculo 1,5-3×0,3-0,4cm, castanho, glabro. Flores andróginas, pediceladas, pedicelo com 4-5×1-1,5mm, castanho, glabro; botões florais alongados, com ápice curvo e agudo. Cálice subulado, castanho-esverdeado, 6-laciniado, persistente, 0,8-1×0,3-0,4cm, glabro. Corola infundibuliforme, rosada, hexâmera, tubo 3-3,8×0,9-1,5cm, curvo, glabro

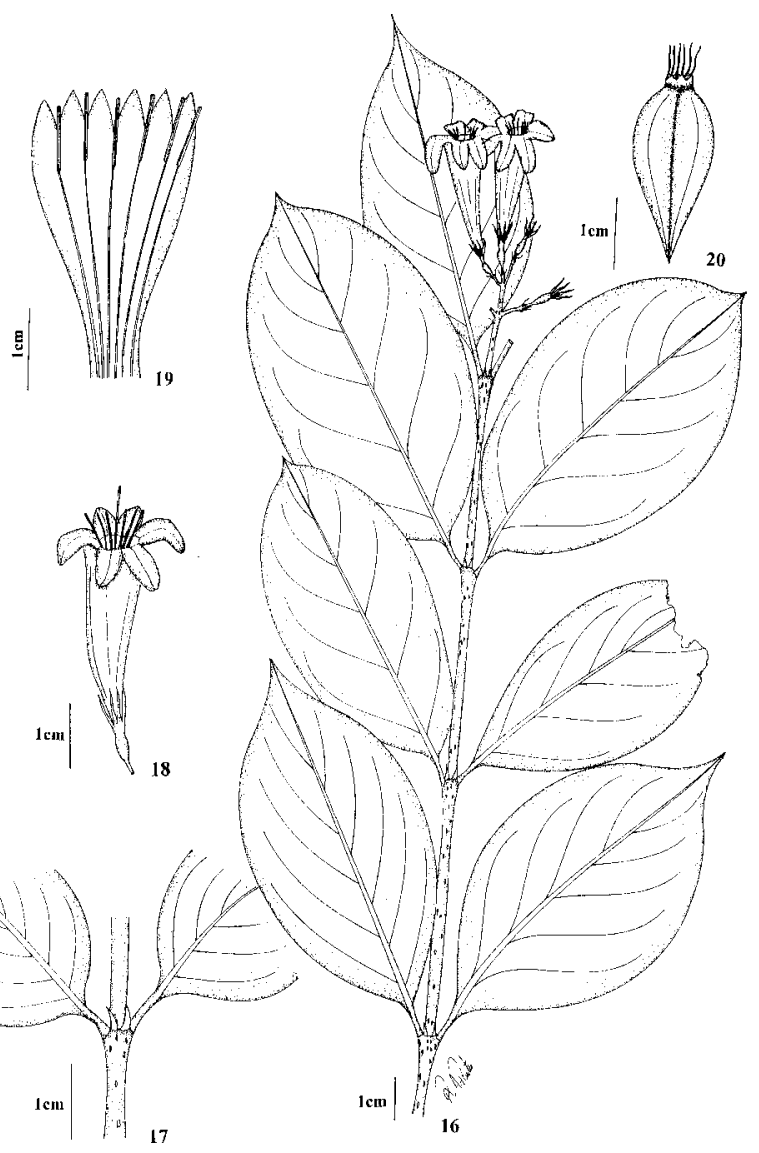

Figuras 16-20. Coutarea hexandra (Pereira 287; 497): 16. Ramo florido. 17. Estípula. 18. Flor. 19. Corola aberta. 20. Fruto. 
externamente e pubérulo internamente apenas na base; lobos 1-1,2×0,5-0,7cm, triangulares, agudos, glabros externa e internamente. Estames 6, exsertos, não concrescidos à corola, afixados na base; filetes $4-5,6 \mathrm{~cm}$ compr., pubérulos apenas na base; anteras 1,3-1,5× $1-1,2 \mathrm{~cm}$, lineares a oblongas, basifixas, amareladas, glabras. Hipanto 0,8-1×0,2-0,3cm, glabro. Ovário bilocular, pluriovular, óvulos horizontais afixados na região mediana do septo, disco nectarífero inteiro. Estilete terminal, exserto, inteiro, espiralado, estriado, 4,5-5,5cm compr., glabro; estigma inteiro, $0,2-0,3 \mathrm{~mm}$ compr., glabro. Cápsula 3-4×1,5-2cm, comprimida, dorsiventral, lenhosa, separando-se longitudinalmente em duas valvas, do ápice para a base, castanha, castanha a negra, glabra. Sementes $1-1,2 \times 0,5-0,7 \mathrm{~cm}$, planas, aladas, alas e estrias circulares.

Material selecionado: BRASIL. Paraíba: Mamanguape, Área I, 23/III/2001, fl., Pereira 335 (JPB); Área II, 24/V/1990, fl., Félix \& Santana 3055 (JPB); 23/II/2001, fl., Pereira 287 (JPB); 29/VI/2001, fr., Pereira 497 (JPB). Rio Tinto, Área III, 30/V/2001, fr., Pereira 374 (JPB).

Material adicional: BRASIL. Paraíba: Cruz do Espírito Santo, 6/V/1981, fr., Agra 332 (JPB); João Pessoa, 23/IV/1980, fl., Agra 274 (JPB), 3/II/1984, fr., Moura s.n. (JPB); Santa Rita, 22/IV/1991, fl., Agra 1308 (JPB); Sousa, 5/II/1998, fl., Gadelha-Neto 394 (JPB). São Paulo: Ubatuba, 16/XI/1993, fl., Spina et al. s.n. (JPB).

Coutarea hexandra tem distribuição neotropical, podendo ser encontrada no México, América Central e do Sul (Schumann 1889; Andersson 1992; Lorence 1999). No Brasil é amplamente distribuída, havendo registros para os Estados do Rio de Janeiro, Amazonas, Minas Gerais, Paraná, São Paulo, Mato Grosso, entre outros (Schumann 1889). Na região Nordeste foi citada por Barbosa et al. (1996), habitando diversos ecossistemas, desde áreas litorâneas até ambientes mais secos do semi-árido; na Paraíba também foi registrada por Barbosa (1996) em uma área remanescente de mata atlântica. Caracteriza-se por apresentar inflorescências paniculadas terminais, corola infundibuliforme com tubo curvo, rosada e anteras basifixas. Em Guaribas foi encontrada nas áreas de mata e nos tabuleiros. Floresce em fevereiro, março, abril, maio, novembro e frutifica em fevereiro, maio, junho.

Tribo Isertieae A. Rich. ex DC.

Arbustos, lianas ou árvores; inflorescências terminais, raramente axilares (Sabicea); ovário bi- hexalocular; frutos carnosos, bacáceos, com sementes numerosas e pequenas.

8. Sabicea cinerea Aubl., Hist. Pl. Gui. Franç. 192. 1775 .

Trepadeira volúvel. Ramos estriados, delgados, cilíndricos, castanhos, tomentosos, tricomas longos e vilosos quando jovens; entrenós $5-11 \mathrm{~cm}$ compr. Estípulas 5-6×2-4mm, inteiras, triangulares, agudas, castanhas, tomentosas, tricomas longos e vilosos. Folhas pecioladas, lâmina $10-15 \times 5-7,5 \mathrm{~cm}$, lanceolada, base aguda a atenuada, ápice agudo, margem inteira, membranácea, castanho-esverdeada a verde-acinzentada quando seca, face superior hirsuta, face inferior tomentosa, adpresso-vilosa, 11-14 pares de nervuras secundárias; pecíolo $0,5-1,3 \times 0,1-0,2 \mathrm{~cm}$, castanhoesbranquiçado, tomentoso. Fascículos axilares, lembrando glomérulos, 1,2-2,5×1-2cm, sésseis a curtopedunculados, com (4)-5-7-(9) flores por fascículo; 4 brácteas com $0,5-1 \times 0,3-0,7 \mathrm{~cm}$, involucrais, foliáceas, ovadas a triangulares, branco-esverdeadas, tomentosas em ambas as faces, 1 bractéola na base de cada flor com 3-5×1-1,5mm, linear a triangular, castanha, hirsuta; pedúnculo 1-2× 2-2,5mm, branco-esverdeado, viloso. Flores andróginas, sésseis, botões florais alongados, lineares, com ápice agudo. Cálice subulado, castanhoesverdeado, 5-laciniado, persistente, 0,7-1,2×0,1-0,3cm, velutino. Corola hipocrateriforme, branca, pentâmera, tubo 1,3-1,7×0,1-0,2cm, velutino externamente e hirsuto internamente do ponto de inserção dos estames até a fauce; lobos 3-4×1-2mm, triangulares, agudos, carnosos, velutinos externamente e glabros internamente. Estames 5, inclusos ou exsertos, afixados no terço superior do tubo; filetes $3-5 \mathrm{~mm}$ compr., glabros; anteras 2-2,5×0,3-0,5mm, lineares a oblongas, obtusas, dorsifixas, amareladas, glabras. Hipanto $3-5 \times 2-3 \mathrm{~mm}$, hirsuto. Ovário pentalocular, pluriovular, óvulos afixados ao septo, disco nectarífero inteiro. Estilete terminal, incluso, dividido em 5 ramos, 0,9-1,1cm compr., glabro; ramos do estilete 2-2,5mm compr., glabros. Baga 0,5-1,2× 0,3-0,4cm, globosa, esférica, roxa a negra, velutina. Sementes $0,1-0,2 \times 0,1-0,2 \mathrm{~mm}$, tetraédricas, cônicas, com micro-estrias longitudinais.

Material selecionado: BRASIL. Paraíba: Mamanguape, Área I, 23/III/2001, fr., Pereira 337 (JPB); Área II, 6/III/1990, fl. fr., Félix \& Santana 2770 (JPB); 29/VI/2001, fl. fr., Pereira 491 (JPB). Rio Tinto, Área III, 18/V/1989, fr., Félix \& Miranda s.n. (JPB); 30/V/2001, fr., Pereira 378 (JPB). 
Material adicional: BRASIL. Paraíba: Santa Rita, 22/IV/1991, fr., Agra \& Góis 1306 (JPB). São Paulo: Ubatuba, 9/XI/1993, fl., Koschnitze et al. s.n. (JPB).

Sabicea cinerea tem ocorrência neotropical (Andersson, 1992), principalmente na América do Sul. No Brasil ocorre em diversas regiões; foi registrada para o Nordeste por Barbosa et al. (1996). Caracteriza-se por ser uma espécie de hábito volúvel, apresentar inflorescências axilares, ovário multilocular e pluriovular e frutos bacáceos com sementes numerosas e pequenas. Em Guaribas é encontrada no interior da mata nas três áreas da unidade. Floresce em março, junho, novembro e frutifica em março, abril, maio, junho.

III. Subfamília Ixoroideae Raf.

Plantas lenhosas; estípulas inteiras; corola com lobos contortos; muitos óvulos por lóculo, raramente um; frutos carnosos.

Tribo Gardenieae A. Rich. ex DC.

Arbustos, árvores ou lianas; inflorescências terminais, raramente axilares; ovário bi-pentalocular; frutos bacáceos.

9. Alibertia myrciifolia K. Schum., Fl. Bras. 6(6): 393. 1889.

Fig. 21-25.

Arbusto, 1,5-2,5m alt. Ramos estriados, espessos nos nós, cilíndricos, cinzas a castanhos, glabros; entrenós $3-11 \mathrm{~cm}$ compr. Estípulas 2-3×2,5-3,5mm, inteiras, triangulares, apiculadas, esverdeadas, glabras. Folhas pecioladas, lâmina $8-17 \times 3-7,5 \mathrm{~cm}$, oblongolanceolada a lanceolada, base obtusa a aguda, ápice agudo a acuminado, margem revoluta, cartácea, cinza a castanha quando seca, glabra em ambas as faces, 6-8 pares de nervuras secundárias; pecíolo 4-7 $\times 1-2 \mathrm{~mm}$, castanho, glabro. Cimas fasciculadas terminais, $1-2 \times 0,5-1,5 \mathrm{~cm}$, curto-pedunculadas, com (2)-4-9-(15) flores por cima, 1 bractéola floral com 0,3-0,5 $\times 0,2-0,3 \mathrm{~mm}$, ovada, esverdeada, glabras; pedúnculo 3-8 $\times 2-3 \mathrm{~mm}$, esverdeado, glabro. Flores unissexuais, sésseis, botões florais alongados, com ápice sagitado. Cálice truncado, esverdeado, persistente, $0,7-1,2 \times 1-1,5 \mathrm{~mm}$, glabro. Flor masculina com corola hipocrateriforme, glabra, amarela, tetrâmera, tubo $0,8-1 \times 0,1-0,2 \mathrm{~cm}$, lobos 3-4×1,5-2 mm, oblongos. Estames 4, inclusos, afixados na porção mediana do tubo, sésseis; anteras 5-6×0,5-1mm, oblongas, apiculadas, dorsifixas, amareladas, glabras. Flor feminina com corola hipocrateriforme, glabra, amarela, tetra-pentâmera, tubo $0,8-1 \times 0,1-0,2 \mathrm{~cm}$, lobos 3-5×1-2mm, oblongos. Hipanto 2-3×1-1,5mm, glabro. Ovário tetra-pentalocular, pluriovular, óvulos multisseriados, disco nectarífero inteiro. Estilete terminal, incluso, inteiro, $6-7 \mathrm{~mm}$ compr., glabro; estigma inteiro, 0,2-0,3mm compr., glabro. Baga 0,8-2×0,9-1,5cm, globosa, preta, glabra. Sementes 4-6 $\times 2-3 \mathrm{~mm}$, triédricas, subcilíndricas, oblongas a ovadas, com uma fenda longitudinal.

Material selecionado: BRASIL. Paraíba: Mamanguape, Área I, 13/XII/2000, fl., Pereira 235 (JPB); 23/III/2001, fl., Pereira 329 (JPB); Área II, 12/I/2001, fr., Pereira 252 (JPB); 23/II/2001, fr., Pereira 265 (JPB); 23/II/2001, fl., Pereira 281 (JPB); 22/III/2001, fl., Pereira 299 (JPB); 22/III/2001, fr., Pereira 304 (JPB); 31/V/2001, fr., Pereira 465 (JPB). Rio Tinto, Área III, 15/XI/2000, fl., Pereira 212 (JPB); 30/V/2001, fl., Pereira 384 (JPB).

Material adicional: BRASIL. Paraíba: Cabedelo, 19/I/2000, fl., Pontes \& Lima 384 (JPB). João Pessoa, 7/III/1995, fr., Barbosa et al. 1423 (JPB); 13/III/1995, fl., Pereira 67 (JPB). Santa Rita, 6/II/1999, fr., Pontes 45 (JPB).

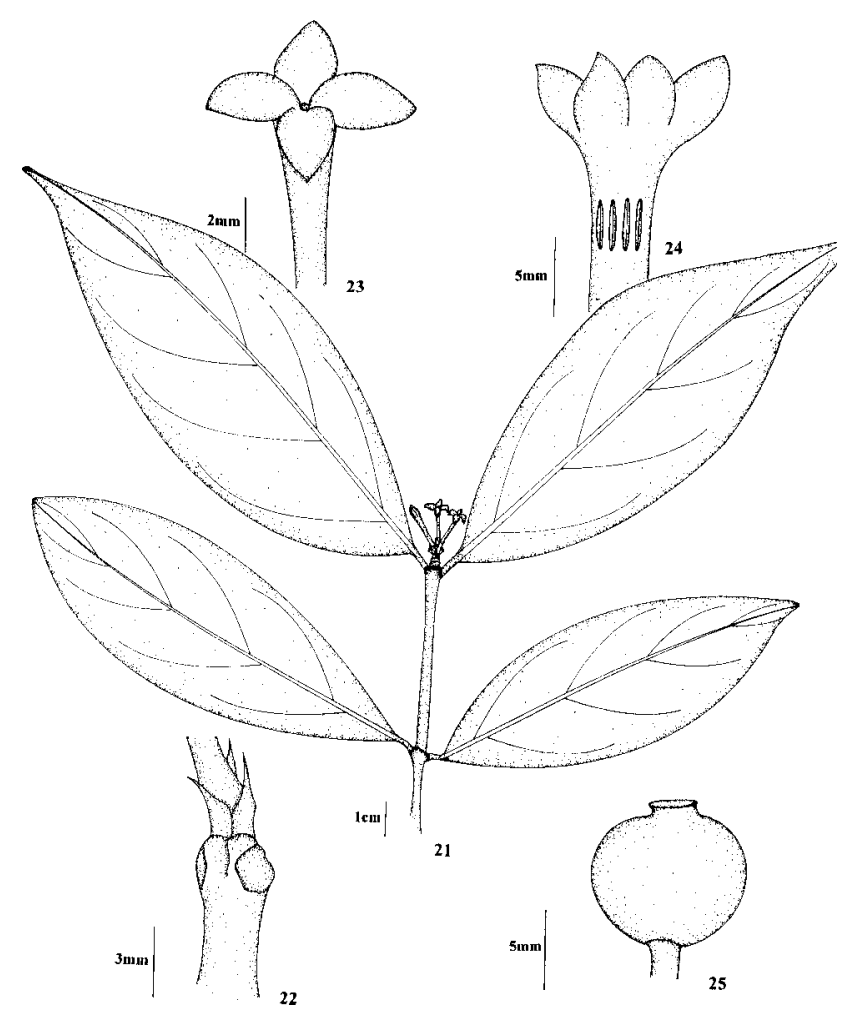

Figuras 21-25. Alibertia myrciifolia (Pereira 299; 304): 21. Ramo florido. 22. Estípula. 23. Corola. 24. Corola aberta. 25. Fruto. 
Alibertia myrciifolia tem distribuição neotropical (Andersson 1992), ocorrendo principalmente na América do Sul; no Brasil foi referida para várias regiões, do Norte ao Sul do país (Schumann 1889; Barbosa et al. 1996; Campos et al. 1999; JungMendaçolli 1999). Na Paraíba foi citada por Barbosa (1996) e Pontes (2000). Diferencia-se das demais espécies estudadas por apresentar flores unissexuais. Em Guaribas é encontrada nas três áreas da unidade, sendo freqüente no interior da mata e nos ambientes de transição mata-tabuleiros. Floresce e frutifica em janeiro, fevereiro, março, maio, novembro e dezembro.

\section{Posoqueria longiflora Aubl., Hist. Pl. Gui. Franç.} 134. 1775.

Arbusto ou arvoreta, 3-6m alt. Ramos estriados, espessos nos nós, cilíndricos, verde-amarelados, glabros; entrenós 5-12cm compr. Estípulas 0,7-1,2× $0,3-0,5 \mathrm{~cm}$, inteiras, triangulares, acuminadas, esverdeadas, glabras. Folhas pecioladas, lâmina 17-21 $\times 4-9,5 \mathrm{~cm}$, oblonga a oblongo-lanceolada, base obtusa a aguda, ápice obtuso a agudo, margem inteira, revoluta, cartácea a subcoriácea, verde-amarelada quando seca, glabra em ambas as faces; 7-10 pares de nervuras secundárias, com a principal proeminente na face inferior; pecíolo $0,5-2 \times 0,1-0,2 \mathrm{~cm}$, amareloesverdeado, glabro. Racemos corimbiformes terminais, pêndulos, $17-22 \times 8-14 \mathrm{~cm}$, pedunculados, com (5)-9-11-(13) flores por corimbo, 2 bractéolas na base de cada flor com 2-3×1-2mm, triangulares, amareladas, glabras; pedúnculo $0,8-2 \times 0,3-0,5 \mathrm{~cm}$, esverdeado, glabro. Flores andróginas, pediceladas, pedicelo com 0,4-1×0,1-0,2cm, esverdeado, glabro; botões florais alongados, curvos no ápice, geniculados, com ápice obtuso. Cálice subulado, esverdeado, 5-laciniado, persistente, $3-5 \times 2-2,5 \mathrm{~mm}$, glabro. Corola hipocrateriforme, branca, pentâmera, tubo $19-25 \times 0,2-0,3 \mathrm{~cm}$, glabro externamente e piloso internamente na fauce; lobos 3-4×0,4-0,7cm, oblongos a oblongo-lanceolados, glabros externamente e pilosos internamente. Estames 5, exsertos, afixados na fauce; filetes 5-9mm compr., glabros; anteras 1-1,3x $0,1-0,2 \mathrm{~cm}$, linear-lanceoladas, acuminadas, basifixas, amareladas, pilosas. Hipanto $1-1,5 \times 0,1-0,2 \mathrm{~cm}$, glabro. Ovário bilocular, pluriovular, óvulos afixados ao longo do septo, disco nectarífero inteiro. Estilete terminal, incluso, bífido, $14-16 \mathrm{~cm}$ compr., glabro; ramos do estilete $2-3 \mathrm{~mm}$ compr., superfície estigmática papilosa. Baga 1,5-3,5×1,5-3cm, globosa a oblonga, coroada pelo cálice persistente, amarela a alaranjada, glabra. Sementes 5-8×3-6mm, cuneiformes, lisas.
Material selecionado: BRASIL. Paraíba: Mamanguape, Área II, 31/V/2001, fl., Pereira 478 (JPB); 31/V/2001, fr., Pereira 479 (JPB). Rio Tinto, Área III, 15/XI/2000, fr., Pereira 219 (JPB).

Material adicional: BRASIL. Paraíba: João Pessoa, 4/V/1995, fr., Pereira 70 (JPB), 25/V/1995, fl., Barbosa 1478 (JPB); Santa Rita, 15/VII/1994, fl., Barbosa \& Lima 1415 (JPB). Pernambuco: Cabo de Santo Agostinho, 19/IX/1989, fl., Agra s.n. (JPB).

Posoqueria longiflora tem distribuição neotropical (Andersson 1992), especialmente na América do Sul (Macias 1988); no Brasil sua distribuição é ampla, principalmente em matas úmidas (Macias 1988; Barbosa 1996; Barbosa et al. 1996). Caracteriza-se por apresentar inflorescências pêndulas, com botões florais curvos no ápice e anteras pilosas. Em Guaribas foi encontrada no interior da mata úmida. Floresce em maio, julho e setembro e frutifica em maio e novembro.

11. Tocoyena formosa (Cham. \& Schltdl.) K. Schum., Fl. Bras. 6(6): 347. 1889.

Gardenia formosa Cham. \& Schltdl., Linnaea 4: 200. 1829.

Árvore ou arvoreta, 2-6m alt. Ramos lisos a parcialmente estriados, espessos, cilíndricos, brancoacinzentados, castanhos, glabros; entrenós $1-2,5 \mathrm{~cm}$ compr. Estípulas 3-5 $\times 4-5 \mathrm{~mm}$, inteiras, triangulares, agudas, caducas, castanhas a ferrugíneas, glabras. Folhas pecioladas, lâmina $9-20 \times 6-11 \mathrm{~cm}$, oblongolanceolada, base obtusa, ápice agudo, margem inteira, cartácea a subcoriácea, verde-amarelada a castanha quando seca, tomentosa, velutina, às vezes híspida em ambas as faces; 7-11 pares de nervuras secundárias, com a principal proeminente na face inferior; pecíolo 0,5-2×0,1-0,2cm, castanho-amarelado, velutino. Dicásios compostos terminais, $12,5-15 \times 2,5-7 \mathrm{~cm}$, pedunculados, com (5)-8-14-(16) flores por dicásio, 1-2 bractéolas na base de cada flor com 1-2×1-2mm, triangulares, castanhas, glabras a pubérulas; pedúnculo 1,5-4×0,2-0,4cm, verde-amarelado, glabro a pubérulo. Flores andróginas, sésseis, botões florais alongados, eretos, com ápice obtuso a curto-acuminado. Cálice campanulado, esverdeado, castanho, persistente, 2-3 $\times 4-5 \mathrm{~mm}$, pubérulo. Corola hipocrateriforme, carnosa, amarela, pentâmera, tubo $9-11 \times 0,3-0,5 \mathrm{~cm}$, piloso externamente e viloso internamente apenas na fauce; lobos 1,5-2,5×0,8-1,5cm, oblongos a obovados, pubérulos externamente e glabros internamente. Estames 5, exsertos, presos na fauce, sésseis; anteras 
7-9 $\times 1-2 \mathrm{~mm}$, lineares a oblongas, curto-apiculadas, dorsifixas, amareladas, glabras. Hipanto 0,9-1,3× 0,4-0,5cm, escabro. Ovário bilocular, pluriovular, óvulos afixados na axila do septo, disco nectarífero inteiro. Estilete terminal, exserto, bífido, bilamelado, $10-15 \mathrm{~cm}$ compr., glabro; ramos do estilete 5-6mm compr., deltóides, glabros. Baga 3,5-5,5×3-4,5cm, globosa a subglobosa, com estrias fibrosas, alaranjada a preta, pubérula a híspida. Sementes $0,8-1,2 \times 0,7-1 \mathrm{~cm}$, planas, dispostas horizontalmente, lisas.

Material selecionado: BRASIL. Paraíba: Mamanguape, Área I, 27/IV/2001, fl., Pereira 367 (JPB); 27/IV/2001, fr., Pereira 370 (JPB); Área II, 15/VI/2000, fr., Pereira 152 (JPB); 22/X/2000, fr., Pereira 199 (JPB); 22/III/2001, fl., Pereira 320 (JPB); 22/III/2001, fr., Pereira 321 (JPB); 28/IX/2001, fr., Pereira 602 (JPB); 5/X/2001, fr., Pereira 630 (JPB).

Material adicional: BRASIL. Paraíba: Cabedelo, 13/VIII/1999, fr., Pontes 101 (JPB); 24/III/2000, fl., Pontes \& Lima 480 (JPB). João Pessoa, 16/XII/1971, fl., Melo s.n. (JPB). Santa Rita, 11/III/1992, fl., Agra \& Góis 1375 (JPB). Sousa, 22/II/1999, fl., Schlindwein 928 (JPB).

Tocoyena formosa tem distribuição neotropical (Andersson 1992). No Brasil, encontra-se nas regiões Centro-Oeste, Sudeste, Norte, Nordeste e Sul, chegando até o Estado do Paraná (Prado, 1987). Na Paraíba foi citada por Pontes (2000). Esta espécie habita vários tipos de vegetação, podendo ser encontrada em matas úmidas e secas, cerrado, caatinga ou ainda em áreas perturbadas. Caracteriza-se por apresentar folhas tomentosas e estípulas caducas. Em Guaribas foi coletada na mata e no tabuleiro. Floresce em fevereiro, março, abril, novembro e frutifica em abril, junho, agosto, setembro, outubro.

12. Tocoyena sellowiana (Cham. \& Schltdl.) K. Schum., Fl. Bras. 6(6): 349. 1889.

Gardenia sellowiana Cham. \& Schltdl., Linnaea 4: 197-198. 1829.

Fig. 26-29.

Árvore ou arvoreta, 3-7m alt. Ramos estriados, espessos, cilíndricos, castanho-acinzentados, glabros; entrenós 1-3cm compr. Estípulas 5-7×4-6mm, inteiras, triangulares, agudas, persistentes, castanhas, glabras. Folhas pecioladas, lâmina $12-17,5 \times 5,5-9,5 \mathrm{~cm}$, obovada a lanceolada, base atenuada a aguda, ápice obtuso a agudo, margem inteira, membranácea a cartácea, castanha a esverdeada quando seca, glabra em ambas as faces; 6-9 pares de nervuras secundárias, com a principal proeminente na face inferior; pecíolo 0,5-2×0,1-0,2cm, castanho-amarelado, glabro. Dicásios compostos terminais, $11-16 \times 3-10 \mathrm{~cm}$, pedunculados, com (6)-9-14-(17) flores por dicásio, 1-2 bractéolas na base de cada flor com 1-1,5×1-2mm, triangulares, castanhas, glabras; pedúnculo 0,5-1×0,3-0,6cm, castanho-amarelado, glabro. Flores andróginas, sésseis, botões florais alongados, eretos, com ápice agudo a curto-acuminado. Cálice campanulado, castanhoesverdeado, persistente, 2-2,5×4-5mm, glabro. Corola hipocrateriforme, carnosa, amarela, pentâmera, tubo $11-12,5 \times 0,4-0,5 \mathrm{~cm}$, glabro externamente e viloso internamente apenas na fauce, lobos $2-2,5 \times 1-1,5 \mathrm{~cm}$, obovados a oblongos, glabros externamente e pubérulopapilosos internamente. Estames 5, exsertos, presos na fauce, sésseis; anteras 0,9-1×0,3-0,4cm, lineares a oblongas, curto-apiculadas, dorsifixas, amareladas, glabras. Hipanto 0,7-1×0,4-0,5cm, glabro. Ovário bilocular, pluriovular, óvulos afixados na axila do septo, disco nectarífero inteiro. Estilete terminal, exserto, bífido, bilamelado, $13,5-15 \mathrm{~cm}$ compr., glabro; ramos do estilete 3-5mm compr., deltóides, glabros. Baga 3,5-5x $3-4 \mathrm{~cm}$, globosa a subglobosa, com estrias fibrosas, alaranjada a preta, glabra. Sementes $0,7-1 \times 0,7-1 \mathrm{~cm}$, planas, dispostas horizontalmente, lisas.

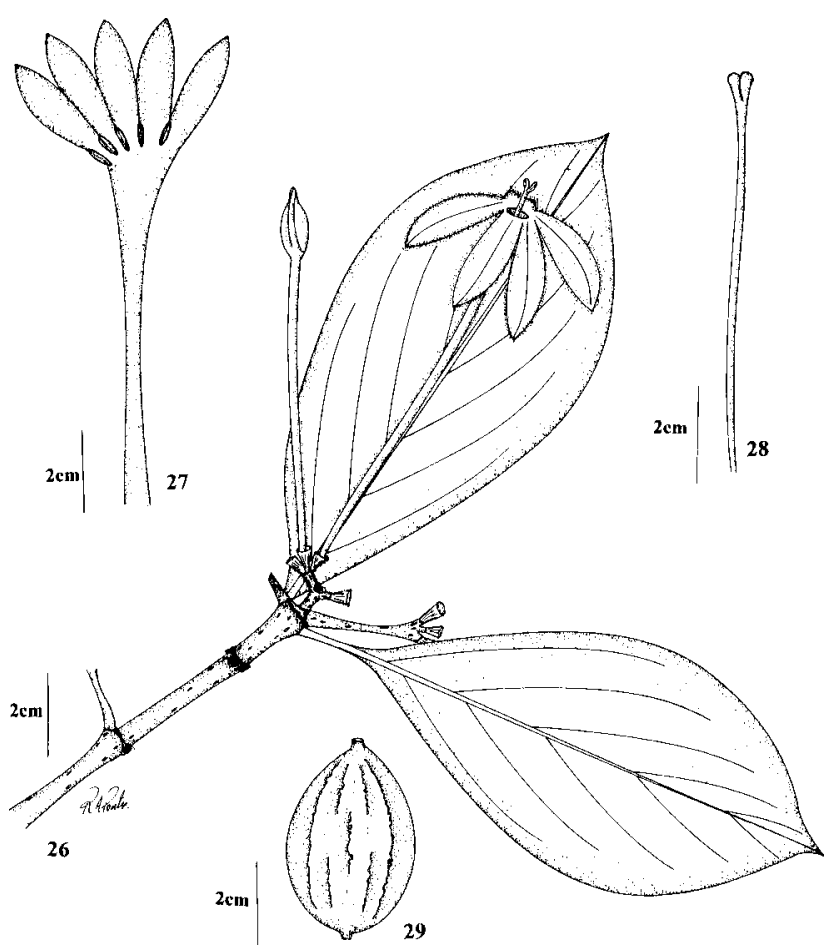

Figuras 26-29. Tocoyena sellowiana (Pereira 323; 518): 26. Ramo florido. 27. Corola aberta. 28. Estilete e estigma. 29. Fruto. 
Material selecionado: BRASIL. Paraíba: Mamanguape, Área II, 23/II/2001, fl., Pereira 263 (JPB); 23/II/2001, fl. fr., Pereira 284 (JPB); 22/III/2001, fl., Pereira 322 (JPB); 22/III/2001, fr., Pereira 323 (JPB); 29/VI/2001, fl., Pereira 518 (JPB).

Material adicional: BRASIL. Paraíba: Cabedelo, 2/VII/1999, fr., Pontes 59 (JPB); 1/III/2000, fl., Pontes \& Lima 422 (JPB).

Tocoyena sellowiana tem distribuição neotropical (Andersson 1992). No Brasil ocorre nos Estados de Alagoas, Bahia, Ceará, Minas Gerais, Pará, Paraná, Paraíba, Pernambuco, Rio de Janeiro, Rio Grande do Norte e Santa Catarina (Prado 1987; Pontes 2000). É geralmente encontrada na mata úmida e em outros ambientes litorâneos. Caracteriza-se por apresentar folhas glabras e estípulas persistentes. Em Guaribas foi coletada na mata e no tabuleiro. Floresce em fevereiro, março, abril e junho e frutifica em fevereiro, março e julho.

\section{Agradecimentos}

As autoras agradecem ao CNPq, pela concessão de bolsas; aos funcionários da REBIO Guaribas, IBAMA/PB; ao Dr. Wm. Wayt Thomas, pela revisão do Abstract; às Dras. Ariane Luna Peixoto e Maria de Fátima Agra, pela revisão criteriosa dos originais.

\section{Referências bibliográficas}

Alain, H.N.O. 1964. Rubiaceae. Flora de Cuba 5: 1-150.

Andersson, L. 1992. A provisional checklist of neotropical Rubiaceae. Scripta Botanica Belgica 1: 1-199.

Barbosa, M.R.V. 1996. Estudo florístico e fitossociológico da Mata do Buraquinho, remanescentes de mata atlântica em João Pessoa, PB. Tese de Doutorado. Universidade Estadual de Campinas, Campinas.

Barbosa, M.R.V. 1997. Nova espécie de Guettarda L. (Rubiaceae, Guettardeae). Bradea 8(11): 61-63.

Barbosa, M.R.V. \& Peixoto, A.L. 1989. As espécies de Simira (Rubiaceae, Rondeletieae) da Amazônia Brasileira. Acta Amazônica 19: 27-46.

Barbosa, M.R.V. \& Peixoto, A.L. 2000. A new species of Simira (Rubiaceae, Rondeletieae) from Northeastern Brazil. Novon 10: 110-112.

Barbosa, M.R.V.; Mayo, S.J.; Castro, A.A.J.F.; Freitas, G.L.; Pereira, M.S.; Gadelha N.P.C. \& Moreira, H.M. 1996. Checklist preliminar das angiospermas. In: E.V.S.B. Sampaio; S.J. Mayo \& M.R.V. Barbosa (eds.). Pesquisa botânica nordestina: progresso e perspectivas. Sociedade Botânica do Brasil, Seção Regional de Pernambuco, Recife.
Barroso, G.M.; Guimarães, E.F.; Ichaso, C.L.F.; Costa, C.G.; Peixoto, A.L. \& Lima, H.C. 1986. Rubiaceae. Pp. 189-229. In: Sistemática de angiospermas do Brasil. v. 3. Universidade Feral de Viçosa, Viçosa.

Barroso, G.M.; Morim, M.P.; Peixoto, A.L. \& Ichaso, C.L.F. 1999. Frutos e sementes: morfologia aplicada à sistemática de dicotiledôneas. Universidade Federal de Viçosa, Viçosa.

Bremekamp, C. 1966. Remarks of the position, the delimitation, and the subdivision of the Rubiaceae. Acta Botanica Neerlandica 15: 1-33.

Brummitt, R.K. \& Powell, C.E. 1992. Authors of plant names. Royal Botanic Gardens, Kew.

Burger, W. \& Taylor, C.M. 1993. Flora Costaricensis. Fieldiana 33: 1-333.

Cabral, E.L. 1996. Cuatro especies nuevas de Borreria (Rubiaceae) para la flora de Brasil. Bonplandia 9(1-2): 35-41.

Cabral, E.L. \& Bacigalupo, N.M. 2000. Novedades en Rubiaceae-Spermacoceae de la flora de São Paulo, Brasil. Boletin de la Sociedad Argentina de Botanica 34(3-4): 149-155.

Campos, M.T.V.A.; Brito, J.M. \& Taylor, C.M. 1999. Rubiaceae. Pp. 625-647. In: J.E.L. Ribeiro; M.J.G. Hopkins; A. Vicentini; C.A. Sothers; M.A.S. Costa; J.M. Brito; M.A.D. Souza; L.H.P. Martins; L.G. Lohmann; P.A.C.L. Assunção; E.C. Pereira; C.F. Silva; M.R. Mesquita \& L.C. Procópio. Flora da Reserva Ducke. Guia de identificação das plantas vasculares de uma floresta de terra-firme na Amazônia Central. INPA, Manaus.

Delprete, P.G. 1999. Rondeletieae (Rubiaceae) Part I. Flora Neotropica. Monograph number 77. OFN. The New York Botanical Garden, New York.

Dillenburg, C.R. \& Porto, M.L. 1985. Rubiaceae tribo Psychotrieae. In: Flora Ilustrada do Rio Grande do Sul. Fasc. XVI. Boletim do Instituto de Biociências 39: $1-76$.

Dwyer, J.D. 1980. Flora de Panama, part IX. Family 179. Rubiaceae. Annals of the Missouri Botanical Garden 67: 1-256.

Figueiredo, M.A.; Fernandes, A.; Diógenes, M.B. \& Oliveira, S.S. 1990. A família Rubiaceae na Serra de Baturité, Ceará. Coleção Mossoroense (749).

Hamilton, C.W. 1989. A revision of mesoamerican Psychotria subgenus Psychotria (Rubiaceae), part I: introduction and species 1-16. Annals of the Missouri Botanical Garden 76: 67-111; part II: Species 17-47. Annals of the Missouri Botanical Garden 76: 386-429; part III: Species and apendices 48-61. Annals of the Missouri Botanical Garden 76: 886-916.

Holmgren, P.K.; Holmgren, N.H. \& Barnett, L.C. 1990. Index Herbariorum, Part I. Ed. 8. The Herbaria of the World., Regnum Veg., New York Botanical Garden, Bronx, New York.

Hooker, J.D. 1873. Rubiaceae. In: G. Benthan \& J.D. Hooker (eds.). Genera Plantarum 2: 7-151.

Jung-Mendaçolli, S.L. 1994. Flora fanerogâmica da Reserva do Parque Estadual das Fontes do Ipiranga (São Paulo, Brasil) Rubiaceae. Hoehnea 21(1/2): 97-129. 
Jung-Mendaçolli, S.L. 1999. Flora fanerogâmica da Ilha do Cardoso (São Paulo, Brasil) Rubiaceae. Pp. 45-136. In: M.M.R.F. Melo et al. (eds.). Flora Fanerogâmica da Ilha do Cardoso. v. 6. Instituto de Botânica, São Paulo.

Lorence, D.H. 1994. New species in Mexican and Mesoamerican Rubiaceae. Novon 4: 119-136.

Lorence, D.H. 1999. A nomenclator of Mexican and Central American Rubiaceae. Missouri Botanical Garden Press, St. Louis.

Mabberley, D.J. 1997. The plant-book: a portable dictionary of the vascular plants. Cambridge University Press, Cambridge.

Macias, L.F.N. 1988. Revisão taxonômica do gênero Posoqueria Aubl. (Rubiaceae). Dissertação de Mestrado. Universidade Estadual de Campinas, Campinas.

Müller Argovensis, J. 1881. Rubiaceae. In: C.F.P. Martius (ed.). Flora Brasiliensis 6(5): 1-470.

Pereira, M.S. 1996. O gênero Psychotria L. (Rubiaceae) na Paraíba, Brasil. Monografia de Graduação. Universidade Federal da Paraíba, João Pessoa.

Pontes, A.F. 2000. Levantamento florístico da Mata da AMEM, Cabedelo, Paraíba - Brasil. Monografia de Graduação. Universidade Federal da Paraíba, João Pessoa.

Porto, M.L.; Jacques, S.M.C.; Miotto, S.T.S.; Waechter, J.L. \& Detoni, M.L. 1977. Tribo Spermacoceae Rubiaceae I. In: Flora Ilustrada do Rio Grande do Sul. Fasc. XII. Boletim do Instituto de Biociências 35: 1-114.

Prado, A.L. 1987. Revisão taxonômica do gênero Tocoyena Aubl. (Rubiaceae) no Brasil. Dissertação de Mestrado. Universidade Estadual de Campinas, Campinas.

Rizzini, C.T. 1977. Sistemática terminológica da folha. Rodriguésia 29(42): 103-125.

Robbrecht, E. 1988. Tropical woody Rubiaceae. Opera Botanica Belgica 1: 1-271.

Rogers, G.K. 1984. Gleasonia, Henriquezia and Platycarpum (Rubiaceae). Flora Neotropica. Monograph number 39. OFN. The New York Botanical Garden, New York.

Schumann, K. 1888. Rubiaceae. In: C.F.P. Martius (ed.). Flora Brasiliensis 6(6): 1-123.

Schumann, K. 1889. Rubiaceae. In: C.F.P. Martius (ed.). Flora Brasiliensis 6(6): 124-466.
Schumann, K. 1891. Rubiaceae. In: Engler, A. \& Prantl, K. (eds.). Die Natürlichen Pflanzenfamilien 4(4): 1-156.

Smith, L.B. \& Downs, R.J. 1956. Resumo preliminar das Rubiáceas de Santa Catarina. Sellowia 7: 13-86.

Souza, E.B. 1997. Estudos taxonômicos dos gêneros Staelia Cham. \& Schltdl. e Mitracarpus Zucc. ex Roem. \& Schult. (Spermacoceae - Rubiaceae) no Estado de Pernambuco, Brasil. Dissertação de Mestrado. Universidade Federal Rural de Pernambuco, Recife.

Standley, P.C. 1930. Rubiaceae of Colombia. Publications of the Field Museum of Natural History, botanical series 7(1): 1-176.

Standley, P.C. 1931. The Rubiaceae of Bolivia. Publications of the Field Museum of Natural History, botanical series 7(3): 253-340.

Standley, P.C. 1936. Rubiaceae. In: Flora of Peru. Publications of the Field Museum of Natural History, botanical series 13(6/1): 3-263.

Steyermark, J.A. 1972. Rubiaceae. In: J.A. Steyermark; B. Maguire (eds.). The Botany of the Guayana Highland, Part. IX. Memoirs of the New York Botanical Garden 23: 227-832.

Steyermark, J.A. 1974. Rubiaceae. In: T. Lasser (ed.). Flora de Venezuela: primeira parte 9: 1-593; secunda parte 9: 603-1101; tercera parte 9: 1111-2070.

Sucre, D. 1959. Rubiaceae da cidade do Rio de Janeiro I, Tribo Spermacoceae. Rodriguésia 33: 241-280.

Sucre, D. 1960/1961. Estudo das Rubiaceae brasileiras I. Rodriguésia 35: 11-20.

Sucre, D. 1971. Estudos das Rubiaceae brasileiras III, cinco novas espécies da tribo Spermacoceae. Rodriguésia 38: 253-260.

Verdcourt, B. 1958. Remarks on the classification of the Rubiaceae. Bulletin du Jardim Botanique de l'État Bruxelles 28: 209-290.

Vidal, W.N. \& Vidal, M.R.R. 1990. Botânica: organografia. Universidade Federal de Viçosa, Viçosa.

Zappi, D. \& Nunes, T.S. 2000. Notes on the Rubiaceae of Northeastern Brazil. I. Erithalis, Psychotria and Rudgea. Kew Bulletin 55: 655-668.

Zappi, D.C. \& Stannard, B.L. 1995. Rubiaceae. In: B.L. Stannard (ed.). Flora of the Pico das Almas, Chapada Diamantina, Bahia, Brazil. Royal Botanic Gardens, Kew. 